\title{
Evaluation of the Nutritional Value of Selected Leafy Vegetables Grown in Sri Lanka
}

\author{
H. Nadeeshani, K.M.S. Wimalasiri ${ }^{1}$, G. Samarasinghe ${ }^{2}$, R. Silva ${ }^{3}$ and T. Madhujith ${ }^{1_{*}}$ \\ Postgraduate Institute of Agriculture \\ University of Peradeniya \\ Sri Lanka
}

\begin{abstract}
Sri Lanka is blessed with a wide variety of leafy vegetables. However, the information on their nutritional value is scanty. In the present study, ten leafy vegetables commonly grown in Sri Lanka, namely Centella asiatica (Gotukola), Alternanthera sessilis (Weda Mukunuwenna), Alternanther asessilis (Common Mukunuwenna), Sesbania grandiflora (Kathurumurunga), Amaranthus viridis (Red thampala), Amaranthus viridis (Green Thampala), Dregea volubilis (Aguna kola), Coccinia grandis (Kowakka), Costus speciosus (Thebu kola) and Trianthema portulacastrum (Sarana) were evaluated for their nutritional composition. Samples of each vegetable species were collected from different geographical locations of the country representing all agro-climatic zones. Healthy, undamaged plant parts were collected, cleaned and air dried at $45{ }^{\circ} \mathrm{C}$, pooled in similar quantities and stored at $4{ }^{\circ} \mathrm{C}$ for further analysis. The proximate and mineral composition of each sample were determined and presented on fresh weight basis. Moisture, ash, crude fat, crude protein and total carbohydrate contents were determined using AOAC standard methods. The moisture content ranged between 76.99 and $89.55 \%$ while the crude protein content ranged between 1.73 and $7.17 \%$. The corresponding ranges for ash, total carbohydrates and crude fat were $1.28-3.86 \%, 4.41-10.76 \%$ and $0.29-1.81 \%$, respectively. Comparatively, $A$. viridis was found to be the richest $(P<0.05)$ source of essential mineral elements.
\end{abstract}

Keywords: Ash, crude fat, crude protein, mineral composition, proximate composition

\section{INTRODUCTION}

An increasing interest has been developed among Sri Lankans towards the consumption of leafy vegetables as means of obtaining nutrients especially micronutrients. Furthermore, many leafy vegetables have been used in traditional medicine for therapeutic and curative purposes. Moreover, many nutritional studies have given an important consideration for dark green leafy vegetables in dietary guidelines as rich sources of vitamins, especially vitamins $\mathrm{C}$ and $\mathrm{A}$; minerals, including calcium, iron and phosphorus; and phytochemicals, particularly antioxidants.

\footnotetext{
1 Department of Food Science and Technology, Faculty of Agriculture, University of Peradeniya, Sri Lanka

2 Plant Genetic Resource Centre, Gannoruwa, Sri Lanka

3 Department of Applied Nutrition, Faculty of Livestock, Fisheries and Nutrition, Wayamba University of Sri Lanka, Sri Lanka

* Corresponding Author: madujith@yahoo.com
} 
The dietary intake of leafy vegetables is negatively associated with many chronic disease conditions such as cardiovascular diseases, cancer, diabetes mellitus, Alzheimer disease, cataract, and age-related functional decline (Willett, 1995; Temple, 2000).The study of Jayawardena et al. (2012) provides evidence that a substantial proportion of the Sri Lankan population acquires meals that include no servings or very few servings of vegetables, though Sri Lanka produces a significant quantity. The daily intake of vegetable portions (1.73) is notably below the national and international recommendations (5 portions). Some part of the population still suffers from one or more micronutrient deficiencies as a result of diets that are deficient in micronutrient-rich foods. The knowledge of nutritional significance can be used for recommendation of leafy vegetables in the diet, mediating nutrient deficiency, nutrient adequacy and nutrient toxicity of a population. Furthermore, compositional data can be incorporated into food consumption surveys, nutrition, agriculture and health policies and programmes. However, nutritional data of green leafy vegetables commonly grown in the country is quite scanty. Therefore, this study was carried out to determine proximate and mineral composition of selected ten leafy vegetables commonly grown and used in food preparations in Sri Lanka namely, Centella asiatica (Gotukola), Alternanthera sessilis ${ }^{1}$ (Weda Mukunuwenna), Alternanthera sessilis ${ }^{2}$ (common Mukunuwenna), Sesbania grandiflora (Kathurumurunga), Amaranthus viridis ${ }^{l}$ (Red Thampala), Amaranthus viridis ${ }^{2}$ (Green Thampala), Dregea volubilis (Aguna kolaThiththaaguna), Coccinia grandis (Kowakka), Costus speciosus (Thebu kola) and Trianthema portulacastrum ( Sarana) (Figures 1-3).

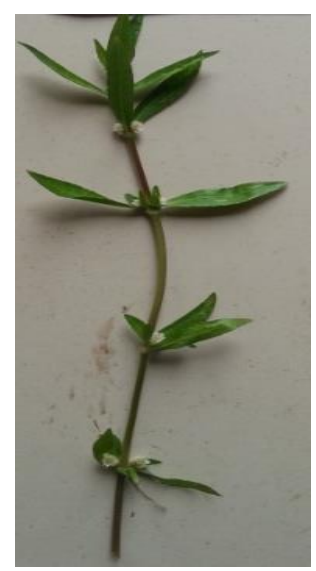

(a)

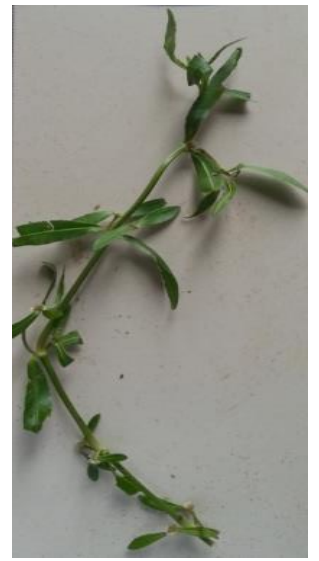

(b)

Figure 1. (a) Alternanthera sessilis (Weda Mukunuwenna) and (b) Alternanthera sessilis (Common Mukunuwenna) 
Nutritional value of selected leafy vegetables grown in Sri Lanka

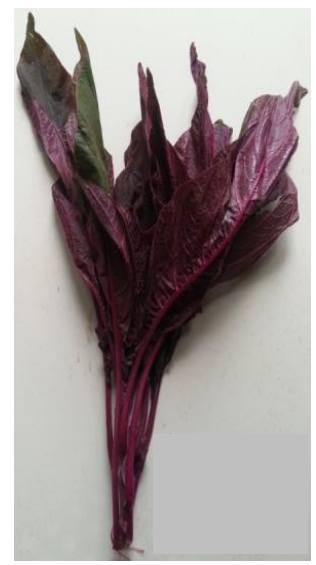

(c)

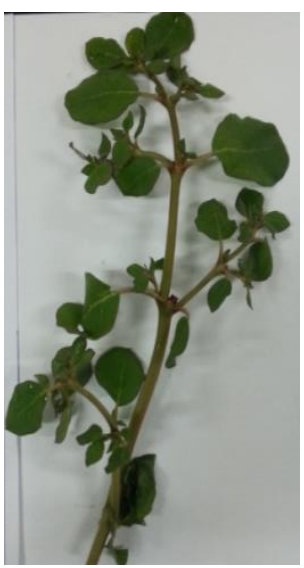

(e)

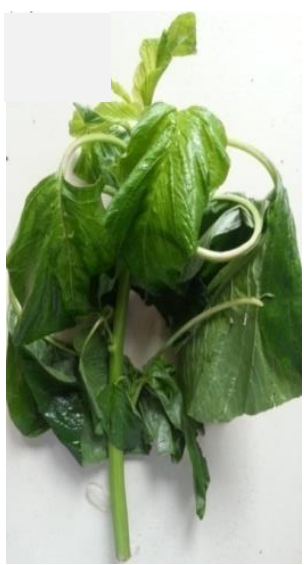

(d)

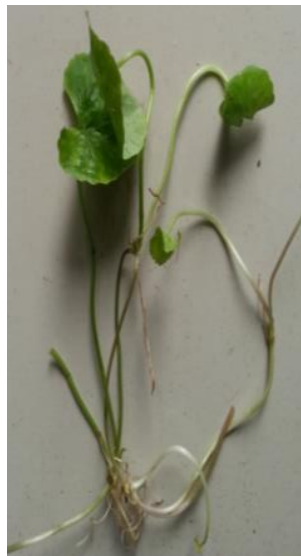

(f)

Figure 2. (c) Amaranthus viridis (Red variety), (d) Amaranthus viridis (Green variety), (e) Trianthema portulacastrum and (f) Centella asiatica

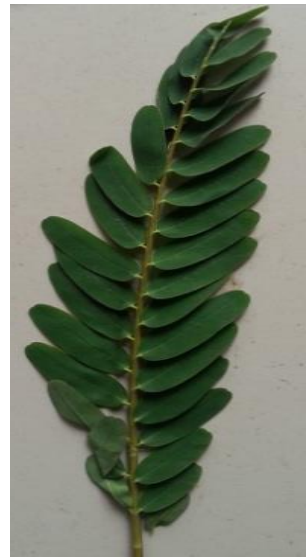

(g)

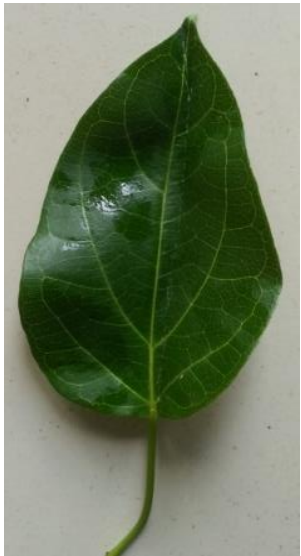

(h) 


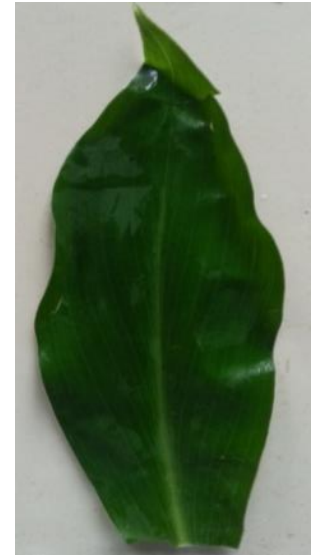

(i)

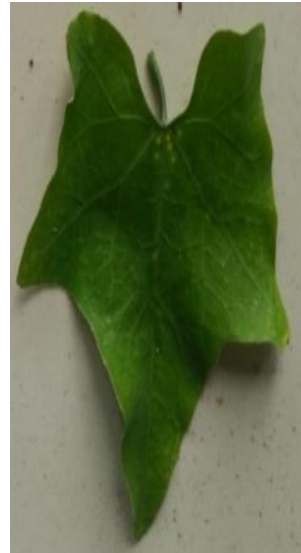

(j)

Figure 3. (g) Sesbania grandiflora, (h) Coccinia grandis, (i) Costus speciosus and (j) Dregea volubilis

\section{MATERIALS AND METHODS}

\section{Materials}

Chemicals: petroleum ether, potassium sulfate, copper sulfate, boric acid, sulphuric acid, sodium hydroxide, bromocresol green and methyl red mixed indicator, hydrochloric acid, sodium carbonate, Devarda's alloy, Phenol, glucose, nitric acid, Rh and Re standards and multi-elemental standards for ICP-MS analysis were purchased from Sigma-Aldrich ${ }^{\mathrm{TM}}$, USA.

\section{Sample collection and preparation}

A total of $500 \mathrm{~g}$ of healthy, undamaged, edible leaves and stems of Centella asiatica, Alternanthera sessilis, Amaranthus viridis and Trianthema portulacastrum and leaves of Sesbania grandiflora, Dregea volubilis, Coccinia grandis and Costus speciosus were collected from seven agro-climatic zones of Sri Lanka: wet zone low country, wet zone mid country, wet zone up country, low country intermediate zone, mid country intermediate zone, up country intermediate zone and low country dry zone separately, packed in polythene bags, labeled, placed in temperature controlled containers and transported to the laboratory without delay.

The plant samples were photographed, identified and authenticated by taxonomists. They were sorted and cleaned appropriately and oven dried at $45{ }^{\circ} \mathrm{C}$ (Phoenix ${ }^{\mathrm{TM}}$, Germany). The oven dried samples from each agro ecological zone were disintegrated in a stainless steel grinder (Apex ${ }^{\mathrm{TM}}$, India), pooled separately in similar quantities and homogenized assuring uniform distribution to prepare the working samples. Oven-dried samples were stored at $4^{\circ} \mathrm{C}$ $\left(\mathrm{LG}^{\mathrm{TM}}\right.$, Japan) for further analyses. 


\section{Proximate analysis}

Methods approved by AOAC (2009) were employed to determine the moisture content of fresh samples and crude protein, fat and ash contents of oven dried samples. The crude protein and crude fat contents were determined using Kjeldahl method (Digester - VELP Scientifica $^{\mathrm{TM}}$, DK 6, Italy and Distillation unit - VELP Scientifica ${ }^{\mathrm{TM}}$, UDK 129, Italy) and Soxhlet extraction methods respectively. The moisture content was determined by drying the sample to a constant weight at $105{ }^{\circ} \mathrm{C}$ in a forced air-oven (SIBATA, SPF-600, Japan). The ash content was determined using gravimetric method by muffle furnace (HOBERSAL ${ }^{\mathrm{TM}}$, HP-150, Spain).

\section{Determination of total carbohydrate content}

The total carbohydrate content was determined according to the method described in AACC 2003 (American Association of Cereal Chemists). A sample (100 mg) was acid-hydrolyzed in a boiling water bath for $3 \mathrm{~h}$ with $5 \mathrm{~mL}$ of $2.5 \mathrm{~N} \mathrm{HCl}$. Then the sample was cooled to room temperature, neutralized with sodium carbonate until the effervescence ceased, made up the volume to $100 \mathrm{~mL}$ and centrifuged at $4000 \mathrm{rpm}$ for $10 \mathrm{~min}$. A sample $(0.1 \mathrm{~mL})$ of the supernatant collected was pipetted out and volume was made up to $1 \mathrm{~mL}$ with distilled water. Blank was set with $1 \mathrm{~mL}$ of distilled water. Five percent of Phenol solution $(1 \mathrm{~mL})$ and $5 \mathrm{~mL}$ of $96 \%$ sulphuric acid were added into each tube, the contents were shaken for 10 minutes and placed in a water bath at $25-30{ }^{\circ} \mathrm{C}$ for $20 \mathrm{~min}$.

All analyses were carried out in triplicate and absorbance was taken using UV/Visible microplate spectrophotometer (Thermo Scientific ${ }^{\mathrm{TM}}$, Genesys $10 \mathrm{~S}$, UK) at $490 \mathrm{~nm}$. Total carbohydrate contents were calculated as percentages using the glucose standard calibration curve (0.0028-0.0143 ppm). The absorbance of the blank was read and necessary corrections were made.

\section{Quantification of the mineral content}

Mineral analysis by inductively coupled plasma mass spectrometer (ICP-MS, iCAPQ, Thermo Scientific, UK) was performed according to the method described by De la Rocha (2009) with some minor modifications. Acid digestion of the oven dried samples $(0.2 \mathrm{~g})$ was performed with $10 \mathrm{~mL}$ of nitric acid $(65 \%$, w/v) using a commercial high-pressure laboratory microwave oven $\left(\mathrm{CEM}^{\circledR}\right.$ Corporation, BR601050, USA), operating by setting the program for $15 \mathrm{~min}$ ramp time, $30 \mathrm{~min}$ holding time during digestion at $180{ }^{\circ} \mathrm{C}$ and $15 \mathrm{~min}$ cooling time. Digested samples were transferred into a $50 \mathrm{~mL}$ volumetric flask, made up to volume with de-ionized water, filtered and stored at $4{ }^{\circ} \mathrm{C}$. Test solutions contained $100 \mu \mathrm{g} / \mathrm{L}$ of $\mathrm{Rh}$ and $\mathrm{Re}$, which were used as internal standards to correct instrumental drift and possible matrix effects. For calibration, multi-elemental standard solutions were prepared with the following concentrations: $0,5,10,30$ and $50 \mathrm{mg} / \mathrm{L}$ for $\mathrm{Na}, \mathrm{Mg}, \mathrm{K}, \mathrm{Al}, \mathrm{Mn}, \mathrm{Zn}, \mathrm{Fe}, \mathrm{Rb}, \mathrm{Sr}$ and $\mathrm{Ba}$; and 0, 0.8, 3.0 and 10.0, 20.0 $\mu \mathrm{g} / \mathrm{L}$ for $\mathrm{Cr}, \mathrm{Co}, \mathrm{Ni}, \mathrm{Cu}, \mathrm{As}, \mathrm{Se}, \mathrm{Li}, \mathrm{Be}, \mathrm{V}, \mathrm{Ga}, \mathrm{Mo}, \mathrm{Cd}$ and $\mathrm{Bi}$. The operating conditions of the ICP-MS for the analysis of the leafy vegetable samples are shown in Table 1. 
Table 1. Operating conditions for ICP-MS

\begin{tabular}{ll}
\hline Parameter & Value \\
\hline Auto Sampler & CETAC ASX-560 \\
Plasma power & $1550 \mathrm{~W}$ \\
Cool gas flow & $14 \mathrm{~L} / \mathrm{min}$ \\
Auxiliary gas flow & $0.65 \mathrm{~L} / \mathrm{min}$ \\
Sample cone & Nickel, $1 \mathrm{~mm}$ orifice diameter \\
Skimmer cone diameter & Nickel, $0.75 \mathrm{~mm}$ orifice \\
Dwell time & $10 \mathrm{~ms}(40 \mathrm{~ms}$ for Se, As $)$ \\
Relative standard deviation & $<1 \%$ \\
(3 replicates) typical & \\
Sample flow & $0.4 \mathrm{~mL} / \mathrm{min}$ \\
Limit of detection, typical & $<0.1 \mathrm{ppb}$ \\
\hline
\end{tabular}

Elements with the highest isotopic abundance were selected as analytical mass. For the within-run assessment, the accuracy and precision of the assays were examined in a single run, with six replicates. For the between-run assessment, TM 25.4 (Environment Canada) for water was analyzed as certified reference material which covered the range of the elements studied such as $\mathrm{Al}, \mathrm{Cr}, \mathrm{Mn}, \mathrm{Co}, \mathrm{Ni}, \mathrm{Cu}, \mathrm{Zn}, \mathrm{As}$, and $\mathrm{Se}$ in six separate runs. Accuracy was defined as the percentage difference between the monitored concentration and the expected value $(\% \mathrm{D})$. Precision was expressed as the percentage of the variation coefficient $(\% \mathrm{CV})$.

Acceptance criteria for accuracy and precision, derived from International Conference on Harmonization (ICH) (1996) rules, were as follows: the mean \%D and \%CV should not exceed $\pm 15 \%$; $75 \%$ of all samples had to be within $\pm 15 \%$ of expected concentrations. In the experiment, no more than one of the six samples within a given concentration could exceed $\pm 15 \%$ of their expected values.

\section{Statistical analyses}

Data for all determinations were subjected to analysis of variance (ANOVA). Complete Randomized Design (CRD) was used as the experimental model and means of experimental data were compared by Duncan's multiple range test $(P<0.05)$. Statistical analyses were conducted using the SAS Statistical Analysis System SAS/IML 14.1 (SAS Institute Inc., Cary, NC).

\section{RESULTS AND DISCUSSION}

\section{Proximate composition}

The proximate composition of leafy vegetables tested in this study is presented in Table 2 . The moisture content of the samples tested ranged between $69.93-87.40 \%$. These values fell within the range $(70-90 \%)$ reported by FAO (2006). Protein content of the samples ranged from $1.73 \mathrm{~g} / 100 \mathrm{~g}$ of fresh weight (FW) in C. speciosus to $7.17 \mathrm{~g} / 100 \mathrm{~g} \mathrm{FW}$ in $S$. grandiflora. The values obtained were rather similar to those reported by Rajapaksha (1998), Odhav et al. (2007) and Longvah et al. (2017). However, quite higher values were reported by Patricia et al. (2014) and Gogoi and Kalita (2014). 
A significantly higher $(P<0.05)$ protein content was observed in $S$. grandiflora compared to all other studied leafy vegetable species. As reported in some studies, leafy vegetables are claimed to be good sources of protein and they could play a considerable role in providing cheap and accessible proteins for rural communities. It was reported that, $100 \mathrm{~g}$ of leafy vegetables could contribute to about 18.6 - 30.92\% of the daily protein requirement (71 g/day) of pregnant and lactating women (FND, 2005), assuming complete absorption of protein. Three species, namely $S$. grandiflora $(1.81 \mathrm{~g} / 100 \mathrm{~g} \mathrm{FW})$, D. volubilis $(1.08 \mathrm{~g} / 100 \mathrm{~g}$ FW) and A. sessilis $(0.75 \mathrm{~g} / 100 \mathrm{~g} \mathrm{FW})$ stand out to be better sources $(P<0.05)$ of fat than other species tested. Crude fat content of studied leafy vegetables ranged from $0.29 \pm 0.00$ $\mathrm{g} / 100 \mathrm{~g} \mathrm{FW}$ to $1.81 \mathrm{~g} / 100 \mathrm{~g} \mathrm{FW}$. The values obtained for lipid content in these leafy vegetable species confirmed the findings of authors such as Rajapaksha (1998), Sheela et al. (2004), Odhav et al. (2007), Lukmanji et al. (2008) and Longvah et al. (2017) which showed that leafy vegetables are poor sources of lipids (Patricia et al., 2014). Furthermore, consumption of leafy vegetables in large amount cannot be detrimental to individuals who are suffering from obesity since diet providing $20-35 \%$ of its caloric energy as fat is stated to be adequate to maintain health and wellbeing of humans and excess fat always leads to the onset non-communicable chronic disease conditions such as cardiovascular disorders, cancer and aging (Kris-Etherton et al., 2002).

Table 2. Proximate composition of leafy vegetables in fresh weight basis (\%)

\begin{tabular}{cccccc}
\hline $\begin{array}{c}\text { Leafy } \\
\text { vegetables }\end{array}$ & Moisture & Ash & Crude fat & $\begin{array}{c}\text { Crude } \\
\text { protein }\end{array}$ & $\begin{array}{c}\text { Total } \\
\text { carbohydrate }\end{array}$ \\
\hline AS1 & $78.98 \pm 2.90^{\mathrm{d}}$ & $3.12 \pm 0.04^{\mathrm{b}}$ & $0.75 \pm 0.00^{\mathrm{c}}$ & $3.00 \pm 0.10^{\mathrm{d}}$ & $10.76 \pm 0.11^{\mathrm{a}}$ \\
AS2 & $84.74 \pm 4.26^{\mathrm{a}}$ & $2.90 \pm 0.21^{\mathrm{b}}$ & $0.73 \pm 0.01^{\mathrm{h}}$ & $2.09 \pm 0.03^{\mathrm{f}}$ & $7.39 \pm 0.25^{\mathrm{e}}$ \\
AV1 & $82.65 \pm 5.02^{\mathrm{b}}$ & $3.86 \pm 0.16^{\mathrm{a}}$ & $0.51 \pm 0.03^{\mathrm{f}}$ & $4.24 \pm 0.04^{\mathrm{b}}$ & $8.46 \pm 0.19^{\mathrm{d}}$ \\
AV2 & $85.75 \pm 2.21^{\mathrm{a}}$ & $2.62 \pm 0.14^{\mathrm{b}}$ & $0.48 \pm 0.00^{\mathrm{h}}$ & $3.10 \pm 0.12^{\mathrm{d}}$ & $6.46 \pm 0.08^{\mathrm{f}}$ \\
CA & $87.34 \pm 2.21^{\mathrm{a}}$ & $1.43 \pm 0.03^{\mathrm{d}}$ & $0.53 \pm 0.03^{\mathrm{e}}$ & $1.75 \pm 0.03^{\mathrm{f}}$ & $7.03 \pm 0.04^{\mathrm{e}}$ \\
SG & $76.99 \pm 2.20^{\mathrm{c}}$ & $2.26 \pm 0.19^{\mathrm{c}}$ & $1.81 \pm 0.08^{\mathrm{a}}$ & $7.17 \pm 0.03^{\mathrm{a}}$ & $9.81 \pm 0.08^{\mathrm{c}}$ \\
DV & $80.17 \pm 3.86^{\mathrm{b}}$ & $1.28 \pm 0.03^{\mathrm{d}}$ & $1.08 \pm 0.06^{\mathrm{b}}$ & $3.41 \pm 0.05^{\mathrm{c}}$ & $10.23 \pm 0.21^{\mathrm{b}}$ \\
CS & $89.01 \pm 3.18^{\mathrm{a}}$ & $1.98 \pm 0.12^{\mathrm{c}}$ & $0.29 \pm 0.00^{\mathrm{h}}$ & $1.73 \pm 0.01^{\mathrm{f}}$ & $5.46 \pm 0.07^{\mathrm{g}}$ \\
CG & $88.95 \pm 2.83^{\mathrm{a}}$ & $1.88 \pm 0.13^{\mathrm{b}}$ & $0.65 \pm 0.06^{\mathrm{d}}$ & $2.62 \pm 0.18^{\mathrm{e}}$ & $5.04 \pm 0.04^{\mathrm{h}}$ \\
TP & $89.55 \pm 4.97^{\mathrm{a}}$ & $3.14 \pm 0.02^{\mathrm{f}}$ & $0.33 \pm 0.00^{\mathrm{f}}$ & $1.75 \pm 0.08^{\mathrm{f}}$ & $4.41 \pm 0.11^{\mathrm{i}}$ \\
\hline
\end{tabular}

Values are average of three independent experiments \pm standard deviation (SD). Means followed by same letters in a column are not significantly different at $P<0.05$ level by Duncan's multiple range test.

Scientific names of leafy vegetable species have been abbreviated as follows; $\underline{A}$. sessilis ${ }^{1}-A S 1, \underline{A} . \underline{\text { sessilis }}{ }^{2}-A S 2, \underline{A}$. viridis $^{I}-A V 1, A$. viridis ${ }^{2}-A V 2, \underline{C}$. asiatica $-C A, \underline{S}$. grandiflora $-S G, \underline{D}$. volubilis $-D V, \underline{C}$. speciosus $-C S, \underline{C}$. grandis $-C G$ and $\underline{T}$. portulacastrum $-T P$

The ash content of leafy vegetables tested varied from $1.28 \pm 0.03 \mathrm{~g} / 100 \mathrm{~g} \mathrm{FW}$ in $D$. volubilis to $3.86 \pm 0.16 \mathrm{~g} / 100 \mathrm{~g} \mathrm{FW}$ in $A$. viridis ${ }^{1}$. The highest total carbohydrate content was observed in $A$. sessilis $^{1}(10.76 \pm 0.11 \mathrm{~g} / 100 \mathrm{~g} \mathrm{FW})$ while $T$. portulacastrum showed the lowest $(4.41 \pm 0.11 \mathrm{~g} / 100 \mathrm{~g} \mathrm{FW})$ among studied leafy vegetables. The ash and carbohydrate contents of most of the leafy vegetables analyzed in this study tallied with the literature (Odhav et al., 2007; Longvah et al., 2017). On the contrary, the higher values for ash and total carbohydrate contents of some studied leafy vegetable species such as A. sessilis and Amaranthus spp. were reported in some published literature such as Gogoi and Kalita (2014) and Patricia et al. (2014) while lower values were reported by Sheela et al. (2004).

\section{Mineral composition}


Mean values for mineral contents of studied leafy vegetables are presented in Table 3.The highest sodium content was observed in the leaves and stems of $T$. portulacastrum $(2.29 \pm 0.031 \mathrm{mg} / \mathrm{g} \mathrm{FW})$ while $C$. speciosus $(0.05 \pm 0.001 \mathrm{mg} / \mathrm{g} \mathrm{FW})$ leaves contained the lowest amount. The leafy vegetable species analyzed in this study contained appreciable amounts of calcium which varied from $3.19 \pm 0.09 \mathrm{mg} / \mathrm{g} \mathrm{FW}$ in $C$. asiatica to $11.17 \pm 0.16 \mathrm{mg} / \mathrm{g} \mathrm{FW}$ in $A$. viridis ${ }^{1}$ and potassium which ranged from $3.92 \pm 0.66 \mathrm{mg} / \mathrm{g} \mathrm{FW}$ in $C$. grandis to $9.98 \pm 0.07$ $\mathrm{mg} / \mathrm{g} \mathrm{FW}$ in $A$. viridis ${ }^{1}$. The highest $(P<0.05)$ content of magnesium was found in leaves and stems of $A$. viridis ${ }^{2}(1.59 \pm 0.003 \mathrm{mg} / \mathrm{g} \mathrm{FW})$ whereas, the lowest $(P<0.05)$ amount of magnesium was found in $C$. asiatica $(0.47 \pm 0.002 \mathrm{mg} / \mathrm{g} \mathrm{FW})$ among all studied leafy vegetables.

It is noteworthy to mention that $A$. viridis ${ }^{2}$ contained the highest $(P<0.05)$ amounts of $\mathrm{Cr}$ $(0.71 \pm 0.022 \mu \mathrm{g} / \mathrm{g} \mathrm{FW}), \mathrm{Fe}(207.34 \pm 8.43 \mu \mathrm{g} / \mathrm{g} \mathrm{FW})$ and $\mathrm{V}(0.51 \pm 0.00 \mu \mathrm{g} / \mathrm{g}$ FW $)$ while $A$. sessilis $^{1}$ was found to contain the highest $(P<0.05)$ amounts of $\mathrm{Mn}(274.72 \pm 5.45 \mu \mathrm{g} / \mathrm{g} \mathrm{FW})$, Co $(0.51 \pm 0.020 \mu \mathrm{g} / \mathrm{g} \mathrm{FW}), \mathrm{Zn}(34.69 \pm 0.75 \mu \mathrm{g} / \mathrm{g} \mathrm{FW}), \mathrm{Ga}(0.534 \pm 0.012 \mu \mathrm{g} / \mathrm{g} \mathrm{FW})$ and Rb $(55.71 \pm 1.38 \mu \mathrm{g} / \mathrm{g} \mathrm{FW})$.The richest source $(P<0.05)$ of $\mathrm{Ni}$ was $D$. volubilis $(0.58 \pm 0.005 \mu \mathrm{g} / \mathrm{g}$ $\mathrm{FW})$ while the poorest $(P<0.05)$ source was $A$. sessilis $^{2}(0.23 \pm 0.001 \mu \mathrm{g} / \mathrm{g} \mathrm{FW})$ among studied leafy vegetables. The barium content of the leaves varied greatly and ranged from $7.85 \pm 0.25 \mu \mathrm{g} / \mathrm{g} \mathrm{FW}$ (C. speciosus) to $49.58 \pm 2.42 \mu \mathrm{g} / \mathrm{g} \mathrm{FW}$ (A. viridis ${ }^{1}$ ).

Copper content in the leafy vegetables tested ranged from $1.50 \pm 0.06 \mu \mathrm{g} / \mathrm{g} \mathrm{FW}$ in $C$. speciosus to $3.94 \pm 0.06 \mu \mathrm{g} / \mathrm{g} \mathrm{FW}$ in $A$. viridis $^{1}$. When compared with other studied leafy vegetables, substantial quantity $(P<0.05)$ of Se was found in $S$. grandiflora $(0.22 \pm 0.017 \mu \mathrm{g} / \mathrm{g}$ FW) whereas the lowest quantity $(P<0.05)$ was observed in $C$. speciosus $(0.03 \pm 0.003 \mu \mathrm{g} / \mathrm{g}$ $\mathrm{FW})$. Molybdenum content varied from $0.215 \pm 0.002 \mu \mathrm{g} / \mathrm{g} \mathrm{FW}$ in $C$. grandis to $0.050 \pm 0.001$ $\mu \mathrm{g} / \mathrm{g} \mathrm{FW}$ in $C$. speciosus. The strontium content also differed in a wide range from $3.11 \pm 0.03$ $\mu \mathrm{g} / \mathrm{g} \mathrm{FW}$ in $T$. portulacastrum to $65.11 \pm 1.66 \mu \mathrm{g} / \mathrm{g} \mathrm{FW}$ in $C$. grandis. The aluminium content varied from $15.43 \pm 0.36 \mu \mathrm{g} / \mathrm{g} \mathrm{FW}$ in $C$. grandis to $86.65 \pm 1.20 \mu \mathrm{g} / \mathrm{g} \mathrm{FW}$ in A. viridis ${ }^{1}$. The minerals found in the least quantities were $\mathrm{Cd}(2.48 \pm 0.20-108.48 \pm 2.16 \mathrm{ng} / \mathrm{g} \mathrm{FW}), \mathrm{Bi}$ $(0.09 \pm 0.01-0.71 \pm 0.33 \mathrm{ng} / \mathrm{g} \mathrm{FW})$, As $(12.15 \pm 1.51-49.04 \pm 2.69 n \mathrm{~g} / \mathrm{g} \mathrm{FW}), \mathrm{Li}(4.71 \pm 0.20-$ $95.28 \pm 1.59 n \mathrm{~g} / \mathrm{g} \mathrm{FW})$ and $\mathrm{Be}(1.23 \pm 0.15-4.80 \pm 0.21 n \mathrm{~g} / \mathrm{g} \mathrm{FW})$. The values of mineral contents observed in this study are comparable with the data published by some other authors (Deraniyagala et al., 1994; Rajapaksha, 1998; Odhav et al., 2007; Gunasekera, 2008; Patricia et al., 2014; Gogoi and Kalita, 2014; Longvah et al., 2017).

Heavy metal accumulation in plants is of rising concern because of the potential human health risks. Contamination of food chain is one of the most critical pathways for the ingress of these toxic heavy metals into the human body. Accumulation of heavy metals in plants is dependent on metal absorbing efficacy of various plant species (Rattan et al., 2005). The presence of heavy metals such as $\mathrm{Pb}, \mathrm{Cr}, \mathrm{As}, \mathrm{Zn}, \mathrm{Cd}, \mathrm{Cu}$, and $\mathrm{Hg}$ in leafy vegetables is highly concerned due to the risk of bioaccumulation and biomagnifications of them in the food chain. These concerned heavy metals contents were comparatively higher in A. sessilis ${ }^{1}$, A. sessilis $^{2}, A$. viridis ${ }^{1}, A$. viridis ${ }^{2}$ and $C$. asiatica than other examined leafy vegetables indicating a potential heavy metal contamination. These leafy vegetable species are cultivated for commercial purpose adding fertilizers and pesticides by Sri Lankan farmers, which may be the most contributing factor for high heavy metal content in them. 
Table 3. Mineral composition of leafy vegetables studied

\begin{tabular}{|c|c|c|c|c|}
\hline Mineral & $\begin{array}{l}\text { A. sessilis (var. Weda } \\
\text { Mukunuwenna) }\end{array}$ & $\begin{array}{l}\text { A. sessilis (var. Common } \\
\text { Mukunuwenna) }\end{array}$ & $\begin{array}{l}\text { A. viridis } \\
\text { (var. Red Thampala) }\end{array}$ & $\begin{array}{l}\text { A. viridis } \\
\text { (var. Green } \\
\text { Thampala) }\end{array}$ \\
\hline $\mathrm{Na}(\mathrm{mg} / \mathrm{g})$ & $0.32 \pm 0.013^{\mathrm{e}}$ & $0.37 \pm 0.002^{f}$ & $1.15 \pm 0.002^{\mathrm{c}}$ & $1.31 \pm 0.004^{b}$ \\
\hline $\mathrm{Mg}(\mathrm{mg} / \mathrm{g})$ & $1.17 \pm 0.007^{\mathrm{b}}$ & $1.023 \pm 0.008^{\mathrm{c}}$ & $1.57 \pm 0.032^{\mathrm{a}}$ & $1.59 \pm 0.003^{\mathrm{a}}$ \\
\hline $\mathrm{K}(\mathrm{mg} / \mathrm{g})$ & $9.18 \pm 0.23^{\mathrm{b}}$ & $8.91 \pm 0.14^{\mathrm{c}}$ & $9.98 \pm 0.07^{\mathrm{a}}$ & $6.32 \pm 0.14^{\mathrm{e}}$ \\
\hline $\mathrm{Ca}(\mathrm{mg} / \mathrm{g})$ & $5.24 \pm 0.13^{f}$ & $3.28 \pm 0.14^{\mathrm{h}}$ & $11.17 \pm 0.16^{\mathrm{a}}$ & $7.45 \pm 0.06^{\mathrm{e}}$ \\
\hline $\mathrm{Al}(\mu \mathrm{g} / \mathrm{g})$ & $38.93 \pm 0.34^{\mathrm{e}}$ & $31.83 \pm 0.21^{\mathrm{f}}$ & $86.65 \pm 1.20^{\mathrm{b}}$ & $140.05 \pm 1.27^{\mathrm{a}}$ \\
\hline $\operatorname{Mn}(\mu \mathrm{g} / \mathrm{g})$ & $274.72 \pm 5.45^{\mathrm{a}}$ & $104.91 \pm 1.48^{c}$ & $105.28 \pm 1.16^{\mathrm{c}}$ & $83.31 \pm 0.27^{\mathrm{f}}$ \\
\hline $\mathrm{Fe}(\mu \mathrm{g} / \mathrm{g})$ & $67.18 \pm 0.98^{\mathrm{d}}$ & $55.16 \pm 1.52^{\mathrm{e}}$ & $156.04 \pm 3.20^{\mathrm{b}}$ & $207.34 \pm 8.43^{\mathrm{a}}$ \\
\hline $\mathrm{Cu}(\mu \mathrm{g} / \mathrm{g})$ & $3.79 \pm 0.03^{\mathrm{b}}$ & $3.17 \pm 0.07^{\mathrm{c}}$ & $3.94 \pm 0.06^{\mathrm{a}}$ & $2.63 \pm 0.07^{\mathrm{d}}$ \\
\hline $\mathrm{Zn}(\mu \mathrm{g} / \mathrm{g})$ & $34.69 \pm 0.75^{\mathrm{a}}$ & $12.39 \pm 0.23^{\mathrm{d}}$ & $16.62 \pm 0.26^{\mathrm{c}}$ & $13.63 \pm 0.11^{\mathrm{d}}$ \\
\hline $\mathrm{Rb}(\mu \mathrm{g} / \mathrm{g})$ & $55.71 \pm 1.38^{\mathrm{a}}$ & $33.28 \pm 1.51^{\mathrm{b}}$ & $20.06 \pm 0.37^{\mathrm{e}}$ & $27.42 \pm 1.55^{\mathrm{d}}$ \\
\hline $\operatorname{Sr}(\mu \mathrm{g} / \mathrm{g})$ & $15.01 \pm 0.66^{\mathrm{f}}$ & $20.12 \pm 0.43^{\mathrm{e}}$ & $53.67 \pm 1.95^{\mathrm{c}}$ & $27.42 \pm 0.43^{\mathrm{d}}$ \\
\hline $\mathrm{Ba}(\mu \mathrm{g} / \mathrm{g})$ & $10.94 \pm 0.07^{\mathrm{f}}$ & $16.30 \pm 0.36^{\mathrm{e}}$ & $49.58 \pm 2.42^{a}$ & $25.88 \pm 0.75^{\mathrm{c}}$ \\
\hline $\mathrm{Cr}(\mu \mathrm{g} / \mathrm{g})$ & $0.31 \pm 0.004^{\mathrm{d}}$ & $0.17 \pm 0.00^{\mathrm{h}}$ & $0.54 \pm 0.031^{\mathrm{b}}$ & $0.71 \pm 0.022^{\mathrm{a}}$ \\
\hline Co $(\mu \mathrm{g} / \mathrm{g})$ & $0.51 \pm 0.020^{\mathrm{a}}$ & $0.33 \pm 0.003^{b}$ & $0.25 \pm 0.002^{\mathrm{c}}$ & $0.48 \pm 0.018^{\mathrm{a}}$ \\
\hline $\mathrm{Ni}(\mu \mathrm{g} / \mathrm{g})$ & $0.57 \pm 0.016^{\mathrm{a}}$ & $0.23 \pm 0.001^{\mathrm{f}}$ & $0.54 \pm 0.005^{\mathrm{b}}$ & $0.49 \pm 0.014^{\mathrm{c}}$ \\
\hline As $(n \mathrm{~g} / \mathrm{g})$ & $37.24 \pm 1.28^{\mathrm{c}}$ & $32.15 \pm 1.51^{\mathrm{f}}$ & $49.04 \pm 2.69^{\mathrm{a}}$ & $42.41 \pm 1.80^{\mathrm{b}}$ \\
\hline $\operatorname{Se}(\mu \mathrm{g} / \mathrm{g})$ & $0.12 \pm 0.004^{\mathrm{c}}$ & $0.08 \pm 0.009^{\mathrm{d}}$ & $0.10 \pm 0.002^{\mathrm{d}}$ & $0.16 \pm 0.002^{b}$ \\
\hline $\mathrm{Li}(n \mathrm{~g} / \mathrm{g})$ & $16.58 \pm 8.56^{\mathrm{e}}$ & $15.69 \pm 8.50^{\mathrm{e}}$ & $73.72 \pm 1.52^{\mathrm{b}}$ & $38.15 \pm 2.70^{\mathrm{c}}$ \\
\hline $\mathrm{Be}(n \mathrm{~g} / \mathrm{g})$ & $1.59 \pm 0.34^{\mathrm{g}}$ & $1.23 \pm 0.15^{\mathrm{i}}$ & $4.65 \pm 0.35^{c}$ & $4.80 \pm 0.21^{\mathrm{b}}$ \\
\hline $\mathrm{V}(\mu \mathrm{g} / \mathrm{g})$ & $0.17 \pm 0.001^{\mathrm{d}}$ & $0.18 \pm 0.001^{\mathrm{d}}$ & $0.35 \pm 0.011^{\mathrm{b}}$ & $0.51 \pm 0.00^{\mathrm{a}}$ \\
\hline $\mathrm{Ga}(\mu \mathrm{g} / \mathrm{g})$ & $0.534 \pm 0.012^{\mathrm{a}}$ & $0.193 \pm 0.012^{\mathrm{f}}$ & $0.252 \pm 0.020^{\mathrm{b}}$ & $0.218 \pm 0.005^{\mathrm{d}}$ \\
\hline Mo $(\mu \mathrm{g} / \mathrm{g})$ & $0.132 \pm 0.0006^{\mathrm{d}}$ & $0.178 \pm 0.005^{\mathrm{b}}$ & $0.161 \pm 0.001^{\mathrm{c}}$ & $0.098 \pm 0.002^{\mathrm{f}}$ \\
\hline $\mathrm{Cd}(n \mathrm{~g} / \mathrm{g})$ & $78.70 \pm 7.32^{\mathrm{b}}$ & $34.65 \pm 1.68^{d}$ & $47.62 \pm 0.21^{\mathrm{c}}$ & $48.47 \pm 0.76^{\mathrm{c}}$ \\
\hline $\mathrm{Bi}(n \mathrm{~g} / \mathrm{g})$ & $0.29 \pm 0.12^{\mathrm{e}}$ & $0.44 \pm 0.13^{c}$ & $0.32 \pm 0.08^{\mathrm{d}}$ & $0.34 \pm 0.06^{\mathrm{d}}$ \\
\hline
\end{tabular}

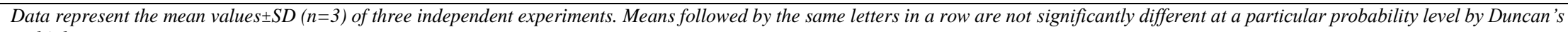
multiple range test. 
Table 3. Mineral composition of leafy vegetables studied

\begin{tabular}{|c|c|c|c|c|c|c|}
\hline Mineral & $\begin{array}{l}\text { C. asiatica } \\
\text { (Wel gotukola) }\end{array}$ & $\begin{array}{l}\text { S. grandiflora } \\
\text { (Kathurumurunga) }\end{array}$ & $\begin{array}{l}\text { D. volubilis } \\
\text { (Aguna kola) }\end{array}$ & $\begin{array}{l}\text { C. speciosus } \\
\text { (Thebu kola) }\end{array}$ & $\begin{array}{l}\text { C. grandis } \\
(\text { Kowakka })\end{array}$ & $\begin{array}{l}\text { T. portulacastrum } \\
\text { (Sarana) }\end{array}$ \\
\hline $\mathrm{Na}(\mathrm{mg} / \mathrm{g})$ & $0.32 \pm 0.004^{\mathrm{e}}$ & $0.29 \pm 0.011^{d}$ & $0.28 \pm 0.005^{\mathrm{d}}$ & $0.05 \pm 0.001^{\mathrm{h}}$ & $0.09 \pm 0.0009^{g}$ & $2.29 \pm 0.031^{\mathrm{a}}$ \\
\hline $\mathrm{Mg}(\mathrm{mg} / \mathrm{g})$ & $0.47 \pm 0.002^{\mathrm{h}}$ & $0.79 \pm 0.001^{\mathrm{e}}$ & $0.95 \pm 0.010^{\mathrm{d}}$ & $0.61 \pm 0.033^{\mathrm{f}}$ & $0.97 \pm 0.001^{\mathrm{d}}$ & $0.51 \pm 0.009^{\mathrm{g}}$ \\
\hline $\mathrm{K}(\mathrm{mg} / \mathrm{g})$ & $4.68 \pm 0.01^{\mathrm{h}}$ & $5.10 \pm 0.08^{\mathrm{g}}$ & $5.37 \pm 0.07^{\mathrm{f}}$ & $5.31 \pm 0.27^{\mathrm{f}}$ & $3.92 \pm 0.66^{\mathrm{i}}$ & $6.97 \pm 0.24^{\mathrm{d}}$ \\
\hline $\mathrm{Ca}(\mathrm{mg} / \mathrm{g})$ & $3.19 \pm 0.09^{\mathrm{h}}$ & $9.65 \pm 0.01^{\mathrm{c}}$ & $9.18 \pm 0.02^{\mathrm{d}}$ & $3.73 \pm 0.11^{\mathrm{g}}$ & $10.73 \pm 0.12^{b}$ & $1.52 \pm 0.01^{\mathrm{i}}$ \\
\hline $\mathrm{Al}(\mu \mathrm{g} / \mathrm{g})$ & $56.21 \pm 0.51^{\mathrm{d}}$ & $19.60 \pm 0.71^{\mathrm{h}}$ & $21.85 \pm 0.06^{\mathrm{g}}$ & $22.87 \pm 0.65^{\mathrm{g}}$ & $15.43 \pm 0.36^{\mathrm{i}}$ & $60.37 \pm 0.16^{\mathrm{c}}$ \\
\hline $\operatorname{Mn}(\mu \mathrm{g} / \mathrm{g})$ & $95.21 \pm 0.14^{\mathrm{e}}$ & $78.31 \pm 0.70^{\mathrm{g}}$ & $99.97 \pm 0.29^{\mathrm{d}}$ & $109.81 \pm 5.35^{\mathrm{b}}$ & $23.65 \pm 0.25^{\mathrm{i}}$ & $47.00 \pm 1.88^{\mathrm{h}}$ \\
\hline $\mathrm{Fe}(\mu \mathrm{g} / \mathrm{g})$ & $93.55 \pm 0.79^{c}$ & $64.92 \pm 0.31^{\mathrm{d}}$ & $48.22 \pm 0.84^{\mathrm{f}}$ & $55.10 \pm 0.02^{\mathrm{e}}$ & $40.65 \pm 0.30^{\mathrm{g}}$ & $91.38 \pm 3.46^{\mathrm{c}}$ \\
\hline $\mathrm{Cu}(\mu \mathrm{g} / \mathrm{g})$ & $2.48 \pm 0.02^{\mathrm{e}}$ & $2.19 \pm 0.14^{\mathrm{f}}$ & $2.47 \pm 0.04^{\mathrm{e}}$ & $1.50 \pm 0.06^{\mathrm{h}}$ & $2.02 \pm 0.01^{\mathrm{g}}$ & $2.11 \pm 0.06^{\mathrm{f}}$ \\
\hline $\mathrm{Zn}(\mu \mathrm{g} / \mathrm{g})$ & $22.89 \pm 0.16^{b}$ & $8.49 \pm 0.09^{\mathrm{e}}$ & $6.86 \pm 0.04^{\mathrm{f}}$ & $4.03 \pm 0.22^{\mathrm{g}}$ & $6.67 \pm 0.00^{\mathrm{f}}$ & $14.08 \pm 0.50^{\mathrm{d}}$ \\
\hline $\mathrm{Rb}(\mu \mathrm{g} / \mathrm{g})$ & $24.96 \pm 0.61^{\mathrm{c}}$ & $26.67 \pm 0.47^{\mathrm{d}}$ & $20.95 \pm 0.226^{\mathrm{d}}$ & $9.63 \pm 0.21^{\mathrm{f}}$ & $7.95 \pm 0.16^{\mathrm{g}}$ & $25.46 \pm 1.98^{c}$ \\
\hline $\mathrm{Sr}(\mu \mathrm{g} / \mathrm{g})$ & $16.81 \pm 0.31^{\mathrm{f}}$ & $28.01 \pm 0.44^{\mathrm{c}}$ & $58.20 \pm 0.54^{\mathrm{b}}$ & $11.35 \pm 0.006^{\mathrm{g}}$ & $65.11 \pm 1.66^{\mathrm{a}}$ & $3.11 \pm 0.03^{\mathrm{h}}$ \\
\hline $\mathrm{Ba}(\mu \mathrm{g} / \mathrm{g})$ & $27.35 \pm 0.09^{c}$ & $20.73 \pm 0.49^{\mathrm{d}}$ & $36.76 \pm 0.16^{\mathrm{b}}$ & $7.85 \pm 0.25^{\mathrm{g}}$ & $47.68 \pm 0.35^{\mathrm{a}}$ & $2.43 \pm 0.17^{\mathrm{h}}$ \\
\hline $\mathrm{Cr}(\mu \mathrm{g} / \mathrm{g})$ & $0.23 \pm 0.001^{\mathrm{f}}$ & $0.19 \pm 0.002^{h}$ & $0.20 \pm 0.006^{\mathrm{g}}$ & $0.40 \pm 0.013^{c}$ & $0.26 \pm 0.003^{\mathrm{e}}$ & $0.26 \pm 0.025^{\mathrm{e}}$ \\
\hline Co $(\mu \mathrm{g} / \mathrm{g})$ & $0.08 \pm 0.0007^{\mathrm{e}}$ & $0.11 \pm 0.003^{\mathrm{d}}$ & $0.08 \pm 0.0004^{\mathrm{e}}$ & $0.06 \pm 0.0006^{\mathrm{f}}$ & $0.03 \pm 0.0002^{\mathrm{g}}$ & $0.13 \pm 0.001^{\mathrm{d}}$ \\
\hline $\mathrm{Ni}(\mu \mathrm{g} / \mathrm{g})$ & $0.46 \pm 0.016^{\mathrm{c}}$ & $0.47 \pm 0.004^{\mathrm{c}}$ & $0.58 \pm 0.005^{\mathrm{a}}$ & $0.36 \pm 0.0007^{\mathrm{d}}$ & $0.29 \pm 0.001^{\mathrm{e}}$ & $0.27 \pm 0.020^{\mathrm{e}}$ \\
\hline As $(n \mathrm{~g} / \mathrm{g})$ & $18.74 \pm 1.06^{\mathrm{e}}$ & $33.99 \pm 1.77^{\mathrm{c}}$ & $31.65 \pm 1.21^{\mathrm{c}}$ & $17.39 \pm 0.41^{\mathrm{e}}$ & $17.50 \pm 3.27^{\mathrm{e}}$ & $21.68 \pm 1.63^{\mathrm{d}}$ \\
\hline $\operatorname{Se}(\mu \mathrm{g} / \mathrm{g})$ & $0.07 \pm 0.003^{\mathrm{d}}$ & $0.22 \pm 0.017^{\mathrm{a}}$ & $0.21 \pm 0.026^{\mathrm{a}}$ & $0.03 \pm 0.003^{\mathrm{f}}$ & $0.05 \pm 0.001^{\mathrm{e}}$ & $0.05 \pm 0.003^{\mathrm{e}}$ \\
\hline $\mathrm{Li}(n \mathrm{~g} / \mathrm{g})$ & $14.19 \pm 0.56^{\mathrm{e}}$ & $26.85 \pm 1.91^{\mathrm{d}}$ & $95.28 \pm 1.59^{\mathrm{a}}$ & $7.24 \pm 1.64^{\mathrm{f}}$ & $4.71 \pm 0.20^{\mathrm{f}}$ & $42.11 \pm 0.23^{\mathrm{c}}$ \\
\hline $\mathrm{Be}(n \mathrm{~g} / \mathrm{g})$ & $3.82 \pm 0.19^{\mathrm{d}}$ & $2.70 \pm 0.23^{\mathrm{e}}$ & $7.97 \pm 0.40^{\mathrm{a}}$ & $1.25 \pm 0.10^{\mathrm{i}}$ & $1.81 \pm 0.08^{\mathrm{f}}$ & $1.47 \pm 0.16^{\mathrm{h}}$ \\
\hline $\mathrm{V}(\mu \mathrm{g} / \mathrm{g})$ & $0.23 \pm 0.004^{\mathrm{c}}$ & $0.08 \pm 0.003^{\mathrm{f}}$ & $0.10 \pm 0.002^{\mathrm{e}}$ & $0.10 \pm 0.001^{\mathrm{e}}$ & $0.07 \pm 0.003^{\mathrm{f}}$ & $0.23 \pm 0.002^{c}$ \\
\hline $\mathrm{Ga}(\mu \mathrm{g} / \mathrm{g})$ & $0.201 \pm 0.002^{\mathrm{e}}$ & $0.199 \pm 0.011^{\mathrm{e}}$ & $0.230 \pm 0.006^{\mathrm{c}}$ & $0.188 \pm 0.003^{\mathrm{g}}$ & $0.045 \pm 0.005^{\mathrm{i}}$ & $0.099 \pm 0.008^{h}$ \\
\hline Mo $(\mu \mathrm{g} / \mathrm{g})$ & $0.104 \pm 0.004^{\mathrm{e}}$ & $0.066 \pm 0.001^{\mathrm{g}}$ & $0.119 \pm 0.001^{\mathrm{e}}$ & $0.050 \pm 0.001^{\mathrm{h}}$ & $0.215 \pm 0.002^{\mathrm{a}}$ & $0.163 \pm 0.010^{c}$ \\
\hline $\mathrm{Cd}(n \mathrm{~g} / \mathrm{g})$ & $108.48 \pm 2.16^{\mathrm{a}}$ & $4.12 \pm 0.14^{\mathrm{g}}$ & $7.58 \pm 1.45^{\mathrm{e}}$ & $2.48 \pm 0.20^{\mathrm{h}}$ & $7.90 \pm 0.02^{\mathrm{e}}$ & $5.70 \pm 0.19^{\mathrm{f}}$ \\
\hline $\mathrm{Bi}(n \mathrm{~g} / \mathrm{g})$ & $0.18 \pm 0.13^{\mathrm{f}}$ & $0.71 \pm 0.33^{\mathrm{a}}$ & $0.30 \pm 0.03^{\mathrm{d}}$ & $0.64 \pm 0.07^{\mathrm{b}}$ & $0.18 \pm 0.04^{\mathrm{f}}$ & $0.09 \pm 0.01^{\mathrm{g}}$ \\
\hline
\end{tabular}

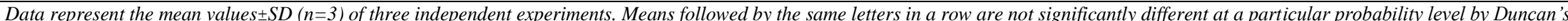
multiple range test. 
Apart from that an overly high amount of As content $(33.99 \pm 1.77 \mathrm{ng} / \mathrm{g} \mathrm{FW})$ was observed in $S$. grandiflora which was as high as the As contents of A. sessilis and A. viridis species. Differences in the chemical composition of leafy vegetables, together with the quantities of compounds and mineral elements that are beneficial and detrimental to humans, is influenced by farming practices, established environmental conditions and age of plants at harvest which affects their nutritional composition (Nordeide et al., 1996). The inorganic arsenic lower limit on the benchmark dose for a $0.5 \%$ increased incidence of lung cancer $\left(\mathrm{BMDL}_{0.5}\right)$ was determined from epidemiological studies to be $3.0 \mu \mathrm{g} / \mathrm{kg}$ of body weight per day (FAO and WHO-JECFA, 2010). According to that, lower limit of As for a person who weighs 60 $\mathrm{kg}$ is $180 \mu \mathrm{g} / \mathrm{d}$. Provisional tolerable monthly intake of Cd is $25 \mu \mathrm{g} / \mathrm{kg}$ body weight (JECFA, 2010). Based on that, provisional tolerable daily intake of $\mathrm{Cd}$ for a person who weighs $60 \mathrm{~kg}$ is $50 \mu \mathrm{g}$. When these recommended tolerable intakes and current consumption patterns of leafy vegetables in Sri Lanka are considered, despite the fact that some leafy vegetables contained substantial amount of As and Cd, they were still far below the harmful levels and a risk is not involved in consumption of these leafy vegetables. However, cumulative effects can be a concern.

\section{CONCLUSIONS}

The results of the study indicate that most of the leafy vegetables are good sources of proteins and minerals (especially $\mathrm{Ca}, \mathrm{Cr}, \mathrm{Cu}, \mathrm{Fe}, \mathrm{Mg}, \mathrm{Mn}, \mathrm{Mo}, \mathrm{Se}, \mathrm{Zn}$ and $\mathrm{K}$ ).S. grandiflora, $D$. volubilis and $A$. sessilis contained higher protein, fat and carbohydrate contents than other studied leafy vegetable species while $T$. portulacastrum and A. sessilis showed higher ash contents than others. Among greatly concerned heavy metals, $\mathrm{Cr}, \mathrm{As}, \mathrm{Zn}, \mathrm{Cd}$ and $\mathrm{Cu}$ contents were comparatively higher in . $_{\text {sessilis }}{ }^{1}, A$. sessilis ${ }^{2}, A$. viridis ${ }^{1}$, A. viridis $^{2}$ and $C$. asiatica than other examined leafy vegetables. Moreover, these results suggest that consumption of sufficient amount of these studied leafy vegetables grown under safe farming practices could beneficially contribute to the nutritional requirement of human. Furthermore, study of the bioavailability of nutrients would be beneficial in food consumption surveys, diet recommendation and in mediating nutrient deficiency, nutrient adequacy and nutrient toxicity of populations.

\section{ACKNOWLEDGEMENTS}

United Nations Environment Programme (UNEP) and Food and Agriculture Organization (FAO) are acknowledged for the financial support. The technical assistant provided by Plant Genetic Resource Centre (PGRC), Department of Agriculture and Department of Geology, Faculty of Science, University of Peradeniya are acknowledged.

\section{REFERENCES}

De la Rocha, S.R., Sanchez-Muniz, F.J., Gómez-Juaristi, M. and Marín, M.L. (2009). Trace elements determination in edible seaweeds by an optimized and validated ICP-MS method. J. Food Comp. Anal. 22(4), 330-336.

Deraniyagala, S.A., Mudalige, K.T., Anula, H.M. and Jamburuthugoda, M.Y.P.R. (1994). Some micronutrient and macronutrient contents of some Sri Lanka food varieties. Vidyodaya J. of Sci. 5(1), 93-102. 
FAO. Proximate composition of foods [online]. [Accessed on 17.07.2017]. Available at http://www.fao.org/ag

FND. Dietary reference intake for energy, carbohydrate, fibre, fat, fatty acids, cholesterol, protein and amino acid (micro-nutrients) [online].[Accessed on 18.07.2017]. Available at http://www.nap.edu

Gogoi, P. and Kalita, J.C. (2014). Proximate analysis and mineral components of some edible medicinally important leafy vegetables of Kamrup district of Assam, India. Int. J. Pharma Bio Sci. 5(4), 451-457.

Gunasekera, L. (2008). Sessile joyweed (Alternanthera sessilis): a popular leafy vegetable in South East Asia but federal noxious weed in USA. In Proceedings of the $16^{\text {th }}$ Australian Weeds Conference, Cairns Convention Centre, North Queensland, Australia. 347-348.

ICH, (1996). International Conference on Harmonization (ICH) of technical requirements for the registration of pharmaceuticals for human use. In: Validation of Analytical Procedures: Methodology, ICH-Q2B, Geneva [online]. [Accessed on 17.07.2017]. Available at http://www.fda.gov/ Cder/Guidance/1320fnl.pdf

World Health Organization. (1993). Evaluation of certain food additives and contaminants: Forty-first Report of the Joint FAO/WHO Expert Committee on Food Additives. In Evaluation of certain food additives and contaminants: Forty-first report of the Joint FAO/WHO Expert Committee on Food Additives.

Kris-Etherton, P.M., Hecker, K.D., Bonanome, A., Coval, S.M., Binkoski, A.E., Hilpert, K. F. and Etherton, T.D. (2002). Bioactive compounds in foods: their role in the prevention of cardiovascular disease and cancer. Am. J. Med. 113(9), 71-88.

Longvah, T., Ananthan, R., Bhaskarachary, K. and Venkaiah, K. (2017). Indian food composition tables. [online]. [Accessed on 12.08.2009]. Available at https://www.researchgate.net/publication/313226719IndianfoodCompositionTables

Lukmanji, Z., Hertzmark, E., Mlingi, N.I.C.O.L.A.S., Assey, V.I.N.C.E.N.T., Ndossi, G. and Fawzi, W. A.F.A.I.E. (2008).Tanzania food composition tables. MUHAS-TFNC, HSPH, Dar es Salaam Tanzania. [online]. [Accessed on 17.07.2017]. Available at https://cdn1.sph.harvard.edu/wp-content/.../tanzania-food-composition-tables.pdf

Nordeide, M.B., Hatloy, A., Folling, M., Lied, E. and Oshaug, A. (1996). Nutrient composition and nutritional importance of green leaves and wild food resources in an agricultural district, Koutiala, in southern Mali. Int. J. Food Sci. Nutr.47, 455-478.

Odhav, B., Beekrum, S., Akula, U.S. and Baijnath, H. (2007). Preliminary assessment of nutritional value of traditional leafy vegetables in KwaZulu-Natal, South Africa. J. Food Comp. Anal. 20(5), 430-435.

Patricia, O., Zoue, L., Megnanou, R.M., Doue, R. and Niamke, S. (2014). Proximate composition and nutritive value of leafy vegetables consumed in Northern Côte d'Ivoire. Eur Sci. J. 10(6), 212-217. 
Rajapaksha, U. (1998). Traditional food plants in Sri Lanka. Hector Kobbekaduwa Agrarian Research and Training Institute, Colombo, Sri Lanka.

Rastogi, A. and Shukla, S. (2013). Amaranth: a new millennium crop of nutraceutical values. Crit. Rev. Food Sci. Nutr. 53(2), 109-125.

Rattan, R.K., Datta, S.P., Chhonkar, P.K., Suribabu, K. and Singh, A.K. (2005). Long-term impact of irrigation with sewage effluents on heavy metal content in soils, crops and groundwater-a case study.Agric. Ecosyst. Environ. 109, 310-322.

Sheela, K., Nath, K.G., Vijayalakshmi, D., Yankanchi, G.M. and Patil, R.B. (2004). Proximate composition of underutilized green leafy vegetables in Southern Karnataka. J. Hum. Ecol. 15(3), 227-229.

Temple, N.J. (2000). Antioxidants and disease: more questions than answers. Nutr Res. 20, 449-459.

Willett, W.C. (1995). Diet, nutrition, and avoidable cancer. Environ. Health Perspect. 103(8), 165-170. 